Article

\title{
Inhibitory Effects on Clinical Isolated Bacteria and Simultaneous HPLC Quantitative Analysis of Flavone Contents in Extracts from Oroxylum indicum
}

\author{
Patchima Sithisarn ${ }^{1}$, Piyanuch Rojsanga ${ }^{2}$ and Pongtip Sithisarn ${ }^{3, *}$ \\ 1 Department of Veterinary Public Health, Faculty of Veterinary Medicine, Kasetsart University, \\ Bangkok 10900, Thailand; fvetphs@ku.ac.th \\ 2 Department of Pharmaceutical Chemistry, Faculty of Pharmacy, Mahidol University, Bangkok 10400, \\ Thailand; piyanuch.roj@mahidol.ac.th \\ 3 Department of Pharmacognosy, Faculty of Pharmacy, Mahidol University, Bangkok 10400, Thailand \\ * Correspondence: pongtip.sit@mahidol.ac.th; Tel.: +66-2-6448701
}

Received: 1 May 2019; Accepted: 15 May 2019; Published: 20 May 2019

\begin{abstract}
Oroxylum indicum is a medicinal plant in Thailand, which has been used as a tonic and for the treatment of various diseases. Extracts from various parts of $O$. indicum were reported as promoting in vitro antioxidant and antibacterial effects. Phytochemical analysis suggested that this plant contained some flavones. O. indicum fruit and seed water and ethanol extracts and their major flavonoids including baicalein, baicalin, and chrysin were tested for in vitro antibacterial activities on four clinical isolated bacteria, namely, Staphylococcus intermedius, Streptococcus suis, Pseudomonas aeruginosa, and $\beta$-Escherichia coli, using a broth micro-dilution assay. The amounts of these three major flavonoids were also quantitatively analyzed using the high-performance liquid chromatographic (HPLC) method. O. indicum fruit ethanol extract from Nakhon Pathom province (OFNE) promoted the strongest antimicrobial activity against four clinical pathogenic bacteria, including $S$. intermedius $\left(\mathrm{IC}_{50}=1.30 \mathrm{mg} / \mathrm{mL}\right)$, S. suis $(13.59 \%$ inhibition at $7.81 \mathrm{mg} / \mathrm{mL})$, P. aeruginosa $\left(\mathrm{IC}_{50}=39.20 \mathrm{mg} / \mathrm{mL}\right)$, and $\beta$-E. coli $\left(\mathrm{IC}_{50}=66.85 \mathrm{mg} / \mathrm{mL}\right)$. Baicalin showed high in vitro antibacterial effect to all tested bacteria. From the optimized and validated HPLC method, baicalin, baicalein, and chrysin contents in $O$. indicum extracts were $0.19 \pm 0.00-9.45 \pm 0.13,0.14 \pm 0.00-1.27 \pm 0.02$, and $0.02 \pm 0.00-0.96 \pm$ $0.02 \mathrm{~g} / 100 \mathrm{~g}$ extract, respectively. Baicalin was found to be the major compound in $O$. indicum seed extract followed by baicalein, whereas chrysin was found in lower amounts than the amounts of the other two flavonoids in all $O$. indicum extracts.
\end{abstract}

Keywords: Oroxylum indicum; baicalin; baicalein; chrysin; Staphylococcus intermedius; Streptococcus suis; broth micro-dilution assay; HPLC

\section{Introduction}

Ethnoveterinary medicine (EVM) is the traditional practice of using natural products, mainly plant extracts, to protect, treat, or support animal health [1]. The close association between humans and their pets and the high growth rate of productive animal industries has led to a high risk of zoonoses. These diseases can cause severe pathologies including septicemia and meningitis, which lead to the increase of antibiotic usage. However, with the realization of the antibiotic resistance crisis in humans and animals, as well as concerns about food safety and the quality of import-export food animal products, a limitation on antibiotic use is now being enforced. The uses for natural products and their active compounds are now of interest. Various secondary metabolites from plants such as volatile oils, alkaloids, phenolics, flavonoids, and anthraquiones were previously reported to promote antibacterial effects. Oroxylum indicum (L.) Vent. is a deciduous tree in the Bignoniaceae 
family. The mature fruit is both acrid and sweet, which promotes anti-helminthic and stomachic effects [2]. The seeds have been used as a purgative, while the seed paste is applied to the throat for the quick relief of tonsil pain [3]. Many flavonoids such as baicalein, biochanin A, oroxylin A, chrysin, apigenin, and their glycosides such as baicalein-7-O-diglucoside (oroxylin B), baicalein-7-O-glucoside, baicalein-6-O-glucoside (tetuin), and scutellarin-7-O-rutinoside were previously reported in the pods, seeds, and root bark of this plant [4-10]. The seeds and pods also contain alkaloids and triterpenes such as ursolic acid $[6,11]$. The seed oil is composed of caprylic, lauric, myristic, palmitic, palmitoleic, stearic, oleic, and linoleic acids [2]. The leaves and stem barks also contain some flavones and flavone glycosides as well as other phenolics such as anthraquinone, tannic acid and ellagic acid, alkaloids, and phytosterols $[4,5,12-14]$.

Our previous reports revealed that ethanol extracts from $O$. indicum fruits exhibited intermediate and moderate in vitro antibacterial activities against Staphylococcus intermedius and Streptococcus suis determined by the disc diffusion method, whereas the seed ethanol extract showed strong in vitro antioxidant activity tested by the DPPH scavenging method. Phytochemical analysis from that study also suggested the presence of baicalein [15]. Another report from our previous study mentioned that the extracts from various plant parts of $O$. indicum such as the leaves, flowers, seeds, stalks, and extracts from tissue-cultured plants and callus exhibited high in vitro antioxidant activities determined by a DPPH scavenging assay with high total phenolic and total flavonoid contents. The phytochemical profiles analyzed by TLC and LC-MS showed the presence of some flavones including baicalin, baicalein, and chrysin [16]. As is known today, flavones, the major and unique compounds in O. indicum, harbor many significant medicinal activities for modern medicinal usages, as our previous report correspondingly suggested with respect to in vitro antibacterial activities of the extracts from the fruits and seeds. However, there is still no report concerning the active compounds and the efficacy of use for this plant against the pathogenic bacteria that can cause lethal meningococcal meningitis and soft tissue bacterial meningitis. The clinical bacterial isolates were selected in order to display the clinical implications which will be very useful for both veterinary medicine and human medicine. In addition, there is no analytical method to simultaneously and quantitatively analyze these flavones. Therefore, in order to investigate the effectiveness of the extracts and clarify the active constituents' ability to inhibit clinical isolated bacteria, six extracts and three major flavones from $O$. indicum, namely, baicalin, baicalein, and chrysin, were determined for the half maximal inhibitory activity $\left(\mathrm{IC}_{50}\right)$ and the ninety-seven percent inhibitory concentrations $\left(\mathrm{IC}_{97}\right)$ on four clinical isolated bacteria using a broth micro-dilution assay-Staphylococcus intermedius, Streptococcus suis, Pseudomonas aeruginosa, and $\beta$-Escherichia coli. The high-performance liquid chromatographic (HPLC) method was optimized and validated for simultaneous quantitative analysis of three major flavone contents in $O$. indicum extracts.

\section{Results}

As shown in Table 1, ethanol extract from the O. indicum fruits collected from Nakhon Pathom province (OFNE) exhibited the strongest inhibitory effects on the selected clinical isolated bacteria. The half maximal inhibitory concentrations $\left(\mathrm{IC}_{50}\right)$ of this extract to inhibit $S$. intermedius, S. suis, P. aeruginosa, and $\beta$-E. coli were $1.30, \%$ inhibition $=13.59$ at the concentration of $7.81 \mathrm{mg} / \mathrm{mL}, 39.20$, and $66.85 \mathrm{mg} / \mathrm{mL}$, respectively. Ethanol extract from O. indicum fruits collected from Chiang Rai province (OFCE) also exhibited an inhibitory effect on S. intermedius with $\mathrm{IC}_{50}$ of $1.96 \mathrm{mg} / \mathrm{mL}$. O. indicum fruit water extracts and seed ethanol and water extracts promoted lower inhibitory effects on the tested bacteria. 
Table 1. Half maximal inhibitory concentrations $\left(\mathrm{IC}_{50}\right)$ of Oroxylum indicum extracts and flavones.

\begin{tabular}{|c|c|c|c|c|}
\hline \multirow{2}{*}{ Sample } & \multicolumn{4}{|c|}{$\mathrm{IC}_{50}(\mathrm{mg} / \mathrm{mL})$} \\
\hline & $\begin{array}{c}\text { Staphylococcus } \\
\text { intermedius }\end{array}$ & Streptococcus suis & $\begin{array}{c}\text { Pseudomonas } \\
\text { aeruginosa }\end{array}$ & $\beta$-Escherichia coli \\
\hline OFND & $7.81^{\mathrm{a}}$ & $>250^{d}$ & $>125^{g}$ & $>250^{d}$ \\
\hline OFNE & 1.30 & $7.81^{\mathrm{e}}$ & 39.20 & 66.85 \\
\hline OFCD & 14.00 & $>250^{d}$ & $>250^{d}$ & $>250^{d}$ \\
\hline OFCE & 1.96 & $7.81^{\mathrm{f}}$ & 61.49 & $>250^{d}$ \\
\hline OSBD & $1.95^{\mathrm{b}}$ & $>250^{d}$ & $>250^{d}$ & $>250^{d}$ \\
\hline OSBE & $>31.25^{c}$ & $>250^{d}$ & 527.01 & $>250^{d}$ \\
\hline Baicalin & 0.36 & 0.53 & 0.22 & 0.33 \\
\hline Baicalein & 2.05 & $>5^{\mathrm{h}}$ & 0.17 & 0.43 \\
\hline Chrysin & $>5^{h}$ & $>5^{h}$ & 0.34 & 1.56 \\
\hline
\end{tabular}

Different letters in the same column are a At a concentration of $7.8 \mathrm{mg} / \mathrm{mL}$, has a $\%$ Bacterial inhibition of $43.70 \%$,

${ }^{b}$ At a concentration of $1.95 \mathrm{mg} / \mathrm{mL}$, has a \% Bacterial inhibition of $23.77 \%{ }^{\mathrm{c}}$ The minimum inhibitory concentration

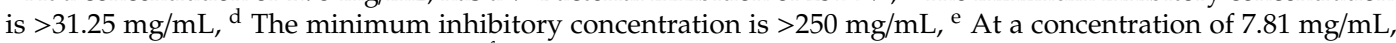
has a \% Bacterial inhibition of $13.59 \%,{ }^{\mathrm{f}}$ At a concentration of $7.81 \mathrm{mg} / \mathrm{mL}$, has a \% Bacterial inhibition of $2.18 \%$, $\mathrm{g}$ The minimum inhibitory concentration is $>125 \mathrm{mg} / \mathrm{mL}, \mathrm{h}$ The minimum inhibitory concentration is $>5 \mathrm{mg} / \mathrm{mL}$. OFND, water extract from $O$. indicum fruits collected from Nakhon Pathom province; OFNE, ethanol extract from $O$. indicum fruits collected from Nakhon Pathom province; $\mathrm{OFCD}$, water extract from $O$. indicum fruits collected from Chiang Rai province; OFCE, ethanol extract from O. indicum fruits collected from Chiang Rai province; OSBD, water extract from O. indicum seeds purchased from Bangkok; OSBE, ethanol extract from O. indicum seeds purchased from Bangkok.

The ninety-seven percent inhibitory concentrations $\left(\mathrm{IC}_{97}\right)$ of baicalin and baicalein to $S$. intermedius were 2.48 and $20,413 \mathrm{mg} / \mathrm{mL}$, respectively, whereas chrysin did not exhibit any effect. The $\mathrm{IC}_{97}$ value of the baicalin to inhibit $S$. suis was $12.43 \mathrm{mg} / \mathrm{mL}$, whereas baicalein and chrysin showed no effect. $P$. aeruginosa showed susceptibility to all three flavones, namely, baicalein, baicalin, and chrysin with $\mathrm{IC}_{97}$ values of $5.99,1.83$, and $1.81, \mathrm{mg} / \mathrm{mL}$, respectively. $\beta$-E. coli displayed susceptibility with $\mathrm{IC}_{97}$ values of $1.86,2.31$, and $169.86 \mathrm{mg} / \mathrm{mL}$ for baicalein, baicalin, and chrysin, correspondingly (Table 2). Almost all substances with activities showed dose-dependent manners, aside from baicalein against S. intermedius that had a gradual increase in inhibition (Figure 1). From the results, baicalein, baicalin, and chrysin could be suggested as an active compound for antibacterial activities in O. indicum in a dose-dependent manner.

Table 2. Ninety-seven percent inhibitory concentrations $\left(\mathrm{IC}_{97}\right)$ of flavones in O. indicum.

\begin{tabular}{ccccc}
\hline \multirow{2}{*}{ Sample } & \multicolumn{4}{c}{$\mathrm{IC}_{\mathbf{9 7}}(\mathbf{m g} / \mathrm{mL})$} \\
\cline { 2 - 5 } & S. intermedius & S. suis & P. aeruginosa & $\boldsymbol{\beta}$-E. coli \\
\hline Baicalin & 2.48 & 12.43 & 1.83 & 2.31 \\
Baicalein & 20,413 & - & 5.99 & 1.86 \\
Chrysin & - & - & 1.81 & 169.86 \\
\hline
\end{tabular}

- signifies no activity. 

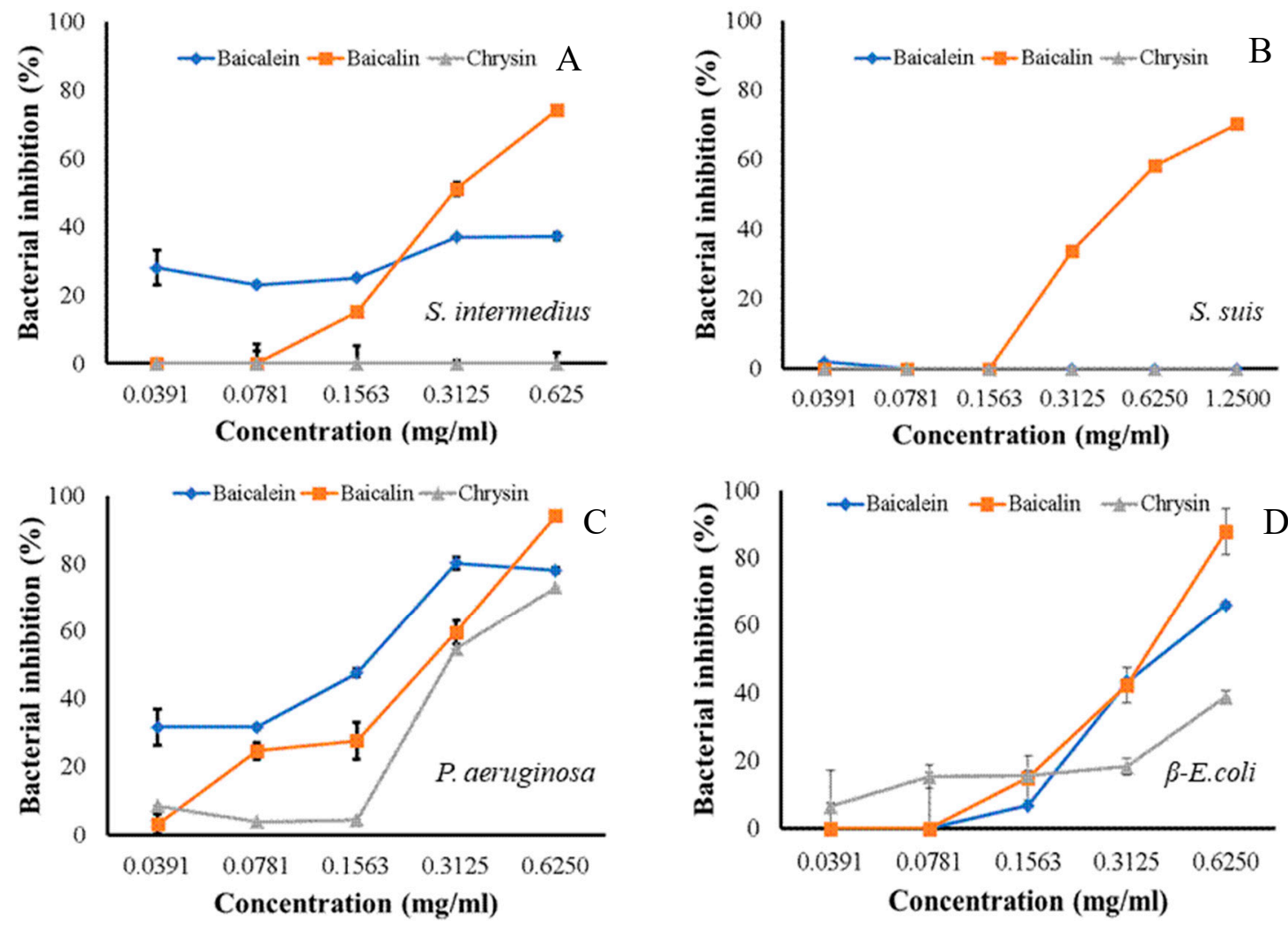

Figure 1. Dose-dependent manners of baicalein, baicalin, and chrysin inhibitory effects against four clinical isolated bacteria: Staphylococcus intermedius (A), Streptococcus suis (B), Pseudomonas aeruginosa (C), and $\beta$-Escherichia coli (D).

Linear correlations from 1.04-104, 1.08-108, and 1.12-112 $\mu \mathrm{g} / \mathrm{mL}$ were obtained from baicalin, baicalein, and chrysin, respectively (Table 3). The $r^{2}$ values for all three compounds were $\geq 0.9990$, confirming the linearity of the method. From the investigation of peak purity, there was no indication of co-elution or impurities from all peaks of interest. The recoveries of all three concentrations of all compounds were close to theoretical amounts (\% recoveries were in the range from 90 to $101 \%$, $\%$ RSD $<2$ ). Percentages of relative standard deviation (\%RSD) of six standard baicalin, baicalein, and chrysin solutions analyzed in three different days (intermediate precision) were less than $5 \%$, while the $\%$ RSD values for repeatability were not more than $2 \%$. Therefore, the method can be regarded as precise. The validation parameters obtained from the optimized HPLC methods were acceptable [17]; therefore, this analytical HPLC method could be used for quantitative analysis of the three flavonoids in the O. indicum extracts. For system suitability parameters, tailing factors of all three standard compounds were less than 2, theoretical plate numbers were in the range of 10,000 to $90,000, \%$ RSD values of the peak area were less than 2 and the standard deviation (SD) values of the retention times of each peak were less than 1 , suggesting the suitability of the analytical method.

Table 3. Calibration data for baicalin, baicalein, and chrysin, including regression equations and correlation coefficient $\left(r^{2}\right)$.

\begin{tabular}{ccc}
\hline Compound & Regression Equation & $r^{2}$ \\
\hline Baicalin & $\mathrm{y}=42947.68 \mathrm{x}-8583.02$ & 0.9997 \\
Baicalein & $\mathrm{y}=64149.91 \mathrm{x}+18864.34$ & 0.9998 \\
Chrysin & $\mathrm{y}=53645.77 \mathrm{x}+10586.07$ & 0.9999 \\
\hline
\end{tabular}

As shown in Table 4, the contents of baicalin, baicalein, and chrysin in all O. indicum extracts were determined using the validated HPLC method. All O. indicum extracts showed similar HPLC 
chromatograms with the peaks corresponding to baicalin, baicalein, and chrysin. From HPLC analysis, baicalin was found to be the major compound in all $O$. indicum extracts, followed by baicalein, whereas chrysin was found in the lowest amount among these flavonoids. The mature seed extracts (OSBD and OSBE) contained the highest amounts of baicalin at $9.03 \pm 0.08$ and $9.45 \pm 0.13 \% w / w$ g extract, respectively, and high amounts of baicalein at $1.27 \pm 0.02$ and $0.91 \pm 0.02 \% w / w$ g extract, respectively. The whole fruit extracts from Nakhon Pathom and Chiang Rai provinces prepared by maceration (OFNE and OFCE, respectively) also contained high amounts of baicalein and moderate amounts of baicalin, whereas OFND and OFCD that are fruit extracts from Nakhon Pathom and Chiang Rai provinces prepared using the decoction method contained low amounts of both baicalin and baicalein contents.

Table 4. Flavonoid contents in O. indicum extracts determined by high-performance liquid chromatographic (HPLC).

\begin{tabular}{cccc}
\hline \multirow{2}{*}{ Sample } & \multicolumn{3}{c}{ Content $(\% w / w \text { in the Extract })^{*}$} \\
\cline { 2 - 4 } & Baicalin & Baicalein & Chrysin \\
\hline OFND & $0.19 \pm 0.00^{\mathrm{a}}$ & $0.14 \pm 0.00^{\mathrm{a}}$ & $0.02 \pm 0.00^{\mathrm{a}}$ \\
OFNE & $1.23 \pm 0.01^{\mathrm{b}}$ & $1.07 \pm 0.02^{\mathrm{b}}$ & $0.44 \pm 0.00^{\mathrm{b}}$ \\
OFCD & $0.37 \pm 0.01^{\mathrm{c}}$ & $0.14 \pm 0.00^{\mathrm{c}}$ & $0.02 \pm 0.00^{\mathrm{c}}$ \\
OFCE & $1.46 \pm 0.01^{\mathrm{d}}$ & $1.23 \pm 0.01^{\mathrm{d}}$ & $0.42 \pm 0.01^{\mathrm{d}}$ \\
OSBD & $9.03 \pm 0.07^{\mathrm{e}}$ & $1.27 \pm 0.02^{\mathrm{d}}$ & $0.96 \pm 0.02^{\mathrm{e}}$ \\
OSBE & $9.45 \pm 0.13^{\mathrm{f}}$ & $0.91 \pm 0.02^{\mathrm{e}}$ & $0.47 \pm 0.01^{\mathrm{f}}$ \\
\hline
\end{tabular}

* Different letters in the same column are significantly different $(p<0.05)$. OFND, water extract from $O$. indicum fruits collected from Nakhon Pathom province; OFNE, ethanol extract from O. indicum fruits collected from Nakhon Pathom province; OFCD, water extract from $O$. indicum fruits collected from Chiang Rai province; OFCE, ethanol extract from O. indicum fruits collected from Chiang Rai province; OSBD, water extract from O. indicum seeds purchased from Bangkok; OSBE, ethanol extract from O. indicum seeds purchased from Bangkok.

\section{Discussion}

From the results, extracts from the young whole fresh fruits of $O$. indicum exhibited a higher inhibitory effect on selected clinical isolated bacteria than the seed extracts, suggesting a higher accumulation of the active compounds in the fruits than the seeds. Ethanol extracts from O. indicum fruits also exhibited stronger inhibitory effects than the water extracts. These results correspond to our previous screening report, which suggested that ethanol extracts from the fruits of $O$. indicum exhibited a higher inhibitory effect on S. intermedius and S. suis than the water extract, whereas both seed ethanol and water extracts exhibited low inhibitory effects [10]. Three major flavones from $O$. indicum exhibited antibacterial effects on the tested bacteria. However, baicalin promoted the highest inhibitory effects, suggesting it is the main active compound in the extract. Our previous phytochemical analysis by LC-MS of extracts from various parts of O. indicum such as whole fruits, seeds, leaves, flowers, stalks, and pedicels suggested that the amounts of baicalin, baicalein, and chrysin in the whole fruit extract are high, especially the amount of baicalin, which is higher than in the other extracts from different plant parts [16]. Baicalin and baicalein also exhibited strong free radical scavenging effects when tested by a DPPH scavenging assay, whereas chrysin exhibited a lower inhibitory effect [16].

The extract from the fruits of $O$. indicum collected from Nakhon Pathom province (OFNE) exhibited the strongest antibacterial effects against all four tested pathogenic bacteria, namely, Staphylococcus intermedius, Streptococcus suis, Pseudomonas aeruginosa, and $\beta$-Escherichia coli, whereas the other five extracts promoted low inhibitory effects. Baicalin was found to be the active constituent for antibacterial activity, whereas baicalein and chrysin promoted a lower, inhibitory effect, except for P. aeruginosa for which chrysin and baicalein showed $\mathrm{IC}_{97}$ values of 1.81 and $5.99 \mathrm{mg} / \mathrm{mL}$, respectively. However, the extracts which contained the highest baicalin contents were OSBD and OSBE $(9.03 \pm 0.08$ and $9.45 \pm 0.13 \% w / w$ of the extract, respectively), showing lower antibacterial effects to the selected pathogenic bacteria, except for OFCE which contained baicalin at $1.46 \% w / w$ of the extract and showed 
low $\mathrm{IC}_{50}$ value against $S$. intermedius of $1.96 \mathrm{mg} / \mathrm{mL}$. From the results, high baicalin contents in OSBE and OSBD seemed to show some correlations to the in vitro antioxidant effects in the results of our previous study [10], but did not show good correlation to the in vitro antibacterial effects. This could be because there is a specific ratio or range of the active flavonoids in $O$. indicum extracts necessary to promote strong antibacterial effect or there could be other active constituents that promote antibacterial activity in O. indicum extracts. Moreover, a previous study reported that there is a fixed oil in the seeds of $O$. indicum [18]. This seed fixed oil could interfere with the antibacterial effects of flavonoids in the seed extracts.

With respect to the mechanism of action, it has been reported that there are two possible mechanisms related to the inhibitory effect on Staphylococcus aureus of the flavonoid-rich traditional Japanese medicine KRT, namely Keigairengyoto, a pharmaceutical-grade traditional Japanese (kampo) medicine comprised of seventeen crude drugs, direct bactericide and immune modulation [19], while another report has suggested that the mechanisms of the antibacterial action are forming a complex with proteins through non-specific forces such as hydrogen bonding and hydrophobic effects, as well as by covalent bond formation, which is related to their ability to inactivate microbial adhesins, enzymes, and cell envelope transport proteins [20]. Baicalein, which is the main compound in KRT, was also reported to have bactericidal effects on S. aureus [21]. The study also suggested that flavonoids circulate as inactive glucuronides and are converted to active aglycones in local inflammatory lesions, possibly by $\beta$-glucuronidase expressing macrophages, in which baicalin, a baicalein-7-O-glucuronide, is one of the key flavonoids mediating the antimicrobial effects [19]. However, there is a study indicating that flavones and isoflavones promoted lower diffusion abilities through the culture medium compared with flavanones and isoflavanones [22]. Normally, conjugation is a common detoxification reaction leading to the increased solubility of compounds, which is important for excretion [23]. Baicalin, a flavone glucuronide, has higher water solubility than its aglycone, baicalein, which could support its ability to be an antibacterial agent. Moreover, the extracts and major flavonoids exhibited stronger inhibitory effects on S. intermedius and S. suis as opposed to P. aeruginosa and $\beta$-E. coli. The results from this study also support the previous data that reported that apigenin-7-O-glucoside, which is a flavone glycoside, had evident antibacterial activity, specifically against Gram-positive bacteria [24]. Distinct from Gram-positive bacteria Staphylococcus and Streptococcus spp., recent studies have shown that Gram-negative bacteria were inhibited by baicalin through the inhibition of important virulence molecules and bacterial quorum sensing pathways. P. aeruginosa was reported to be inhibited by baicalin through controlling quorum sensing (QS)-controlled virulence factor and biofilm formation [25]. Additionally, baicalin was reported as interfering with lethal Escherichia coli (STEC) O157:H7 infections by inducing a Shiga-like toxin 2 (Stx2) to form inactive oligomers [26]. The differences in the mechanisms of flavonoids in inhibiting bacteria may expose distinctive patterns of inhibition and differences in dose-dependent manners.

From our study, OFNE could be a good source for antibacterial activity against four selected pathogenic bacteria, and all three flavonoids, namely, baicalin, baicalein and chrysin, could be used to control the quality of the extracts. The seeds of $O$. indicum are good sources to obtain high amounts of active flavonoids; extraction by maceration with $95 \%$ ethanol promoted extracts with higher amounts of these flavonoids than decoction. O. indicum whole fruits from Nakhon Pathom and Chiang Rai provinces contained flavonoid contents in the near ranges. Therefore, O. indicum fruit ethanol extracts could be further developed for pharmaceutical or medicinal purposes for their antibacterial effects.

\section{Materials and Methods}

\subsection{Chemicals}

Deionized water was obtained by using a water purification system from Thermo Scientific Co. (Waltham, MA, USA). Standard baicalin and chrysin, at a pharmaceutical grade, were purchased from TRC (North York, ON, Canada), and baicalein, at an analytical reference grade, was purchased from 
Sigma-Aldrich (St. Louis, MO, USA). DMSO was purchased from Sigma-Aldrich (St. Louis, MO, USA). Mueller-Hinton broth powder was purchased from Oxoid (Basingstoke, UK). Acetonitrile was purchased from Sigma-Aldrich (St. Louis, MO, USA), whereas phosphoric acid was purchased from Merck (Darmstadt, Germany).

\subsection{Plant Materials}

The fruits from Oroxylum indicum were separately collected from Chiang Rai and Nakhon Pathom provinces, whereas the mature seeds were purchased from a traditional herbal shop in Bangkok in 2015. Plant samples were cleaned and dried in a hot air oven (Memmert, Schwabach, Germany) at $60^{\circ} \mathrm{C}$, then ground using an electric mill (Ika-Werke, Staufen, Germany) (20 mesh sieve).

\subsection{Bacteria and Reagents}

Clinical isolates of Staphylococcus intermedius, Streptococcus suis, Pseudomonas aeruginosa, and $\beta$-Escherichia coli were obtained from the Microbiological Laboratory, Veterinary Diagnostic Center, Faculty of Veterinary Medicine, Kasetsart University, Nakhon Pathom, Thailand. The bacteria strains were isolated and characterized using differential bacterial culture and biochemical assays for clinical samples according to the standard method of Baron et al. [27]. S. Suis, P. aeruginosa, and $\beta$-E. coli were maintained in Microbank Cryovials and kept at $-80^{\circ} \mathrm{C}$. Staphylococcus intermedius was maintained in skimmed milk at $-40^{\circ} \mathrm{C}$ until use. Blood agar was obtained from the Bacteriology Unit. Antibiotics amoxicillin, doxycycline, and gentamicin were purchased from Sigma-Aldrich (St. Louis, MO, USA).

\subsection{Plant Extract Preparations}

Each sample of $O$. indicum fruit and seed powder was separately extracted by maceration using $95 \%$ ethanol and decoction with distilled water (plant:solvent ratio 1:20 w/v). For decoction, each powdered plant sample was separately boiled with distilled water at $100{ }^{\circ} \mathrm{C}$ for $2 \mathrm{~h}$ and filtered, whereas for maceration, each powdered plant sample was separately macerated with $95 \%$ ethanol using an electric flask shaker (Wisd Laboratory Instruments, Wertheim, Germany) for $6 \mathrm{~h}$. After the extract was kept for $12 \mathrm{~h}$, the extraction solution was filtered. Each extraction process was repeated three times. The extraction solutions were then combined, filtered, and evaporated using a water bath to yield the dried extracts.

\subsection{Bacteria Culture}

Prior to sensitivity testing, each bacterial strain was maintained on a blood agar plate and incubated for $18-24$ h at $37^{\circ} \mathrm{C}$.

\subsection{Flavonoid Preparation}

Flavonoids were dissolved in DMSO to reach the concentrations ranging between 0.0391 and $5 \mathrm{mg} / \mathrm{mL}$ and stored at $4{ }^{\circ} \mathrm{C}$ for further use. Flavonoid stocks were maintained at $-20^{\circ} \mathrm{C}$.

\subsection{Broth Micro-Dilution Assay}

Inoculum preparation. Bacteria inoculums were obtained from suspended bacterial colonies in fresh Mueller-Hinton ( $\mathrm{MH}$ ) broth. The density of the bacteria culture required for the test was adjusted to $0.5 \mathrm{McF}$ arland standard $\left(1.0 \times 10^{8} \mathrm{CFU} / \mathrm{mL}\right)$ in $10 \mathrm{~mL} \mathrm{MH}$ broth using a turbidimeter (BioSan, Rīga, Latvia). The inoculum suspensions were divided in each well containing approximately $1 \times 10^{6}$ CFU/well.

Extracts preparation. Ethanol and water extracts were dissolved in 95\% ethanol and water, respectively. The stock extract solutions were prepared at a concentration of $100 \mathrm{mg} / \mathrm{mL}$. Two-fold serial dilution was done in a 96-well microplate. The final concentrations of the extracts in each well were in the range of $9.78-250 \mathrm{mg} / \mathrm{mL}$. 
Amoxicillin, doxycycline, and gentamicin. Portions of $0.1 \mathrm{mg} / \mathrm{mL}$ were used as the standard controls for all experiments. The microplates were incubated at $37^{\circ} \mathrm{C}$ for $24 \mathrm{~h}$. The results were obtained by detecting the absorbance values at time intervals of 0,18 , and $24 \mathrm{~h}$ using a microplate reader (Tecan, Redwood City, CA, USA) at a wavelength of $625 \mathrm{~nm}$. The bacterial growth curves were made and the inhibitory activities were then determined. The half maximal inhibitory concentration $\left(\mathrm{IC}_{50}\right)$ values were calculated using CalcuSyn 2.1 software (Biosoft, Cambridge, UK), whereas the ninety-seven percent inhibitory concentration $\left(\mathrm{IC}_{97}\right)$ values were calculated using CompuSyn 1.0 software (Combosyn Inc., Paramus, NJ, USA).

\subsection{Analysis of Flavone Contents in O. indicum Extracts by HPLC}

Quantitative analysis of the three flavones in the O. indicum extracts, namely, baicalin, baicalein and chrysin, was conducted using the HPLC method that was validated as described below.

High-performance liquid chromatographic analysis of baicalin, baicalein, and chrysin was performed using a Shimadzu LC-10ADVP system (Kyoto, Japan) equipped with a diode array detector (DAD) SPD-M10AVP and a column heater (Shimadzu, Kyoto, Japan). An X-terra C18 column (150 mm $\times 3.9 \mathrm{~mm}, 5 \mu \mathrm{m}$ particle size) from Waters (Milford, MA, USA) was used. Gradient elution was performed with water- $0.01 \%$ phosphoric acid (solvent A) and acetonitrile (solvent B) at a constant flow rate of $1.2 \mathrm{~mL} / \mathrm{min}$. Column temperature was $40^{\circ} \mathrm{C}$ with an injection volume of $20 \mu \mathrm{L}$; detection was performed at $285 \mathrm{~nm}$.

Linearity for standard baicalin, baicalein, and chrysin was determined by analysis of seven different concentrations, each injected in triplicate. Peak purity was investigated using a DAD for all peaks of interest. The precision of the method was evaluated by analyzing six independently prepared solutions of standard baicalin, baicalein, and chrysin on three different days. The peak area of each standard compound was determined and the relative standard deviation percent (\%RSD) was calculated. The accuracy of the method was confirmed by determination of the recovery. The recovery of standard compounds was performed on samples spiked with three concentrations of each compound $(10,20$, and $30 \mu \mathrm{g} / \mathrm{mL})$. The validated HPLC analytical method was then applied for quantitative analysis of baicalin, baicalein, and chrysin in O. indicum fruit and seed extracts. System suitability of the analytical method, including tailing factor, theoretical plate, \%RSD of peak area and SD of retention time, was also investigated.

\section{Conclusions}

From all of the results, O. indicum fruit and seed extracts showed significant in vitro antibacterial effects against four pathogenic bacteria, namely, Staphylococcus intermedius, Streptococcus suis, Pseudomonas aeruginosa, and $\beta$-Escherichia coli. These extracts, especially the extract from the fruits of O. indicum collected from Nakhon Pathom province (OFNE), could be major natural sources for development as a health supplement or herbal medicines in the future, particularly for the antibacterial effect to treat zoonotic diseases such as meningococcal meningitis and soft tissue bacterial meningitis. These flavonoids, namely, baicalin, baicalein, and chrysin, could be used as chemical markers for the quality control of $O$. indicum fruit and seed extracts. The relation between the flavonoid contents in the seed extracts and their antibacterial effects should be investigated. The optimized and validated HPLC method that was obtained in this study could be used for quantitative analysis of flavonoids in O. indicum fruit and seed extracts. Studies about the mechanism of action, toxicity, development of herbal formulation, and stability tests should be performed in the future.

Author Contributions: Conceptualization, P.S. (Patchima Sithisarn), P.R. and P.S. (Pongtip Sithisarn); methodology, P.S. (Patchima Sithisarn), P.R and P.S. (Pongtip Sithisarn); software; P.S. (Patchima Sithisarn) and P.R.; validation, P.S. (Patchima Sithisarn) and P.R; formal analysis P.S. (Patchima Sithisarn), P.R and P.S. (Pongtip Sithisarn); investigation P.S. (Patchima Sithisarn), P.R and P.S. (Pongtip Sithisarn); resources, P.S. (Patchima Sithisarn) and P.S. (Pongtip Sithisarn); data curation, P.S. (Patchima Sithisarn), P.R and P.S. (Pongtip Sithisarn); writing-original draft preparation, P.S. (Patchima Sithisarn), P.R. and P.S. (Pongtip Sithisarn); writing-review and editing, P.S. (Patchima Sithisarn) and P.S. (Pongtip Sithisarn); visualization, P.S. (Patchima Sithisarn) and P.S. (Pongtip Sithisarn); 
supervision, P.S. (Pongtip Sithisarn); project administration, P.S (Pongtip Sithisarn).; funding acquisition, P.S. (Pongtip Sithisarn).

Funding: This research received no external funding.

Acknowledgments: The authors would like to thank Petcharat Nantateerapong, Suksan Chamsing, Somyod Kankhuntod, and Montisha Suwanwong for technical support.

Conflicts of Interest: The authors declare no competing financial interests.

\section{References}

1. McGaw, L.J.; Van der, M.D.; Eloff, J.N. In vitro anthelmintic, antibacterial and cytotoxic effects of extracts from plants used in South African ethnoveterinary medicine. Vet. J. 2007, 173, 366-372. [CrossRef] [PubMed]

2. Harminder, S.V.; Chaudhary, A.K. A review on the taxonomy, ethnobotany, chemistry and pharmacology of Oroxylum indicum Vent. Indian J. Pharm. Sci. 2011, 73, 483-490.

3. Warrier, P.K.; Nambiar, V.P.K.; Ramankutty, C. Indian Medicinal Plant: A Compendium of 500 Species (4); Orient Longman: Hyderabad, India, 1993; pp. 186-190.

4. Subramaniam, S.S.; Nair, A.G. Flavonoids of the stem bark of Oroxylum indicum. Curr. Sci. 1972, 41, $62-63$.

5. Jayaram, K.; Prasad, M.N. Genetic diversity in Oroxylum indicum (L.) Vent. (Bignoniaceae), a vulnerable medicinal plant by random amplified polymorphic DNA marker. Afr. J. Biotechnol. 2008, 7, 254-262.

6. Bhattacharje, A.K.; Das, A.K. Phytochemical screening of some Indian plants. J. Crude Drug Res. 1969, 9, 1408-1412. [CrossRef]

7. Chen, L.J.; Games, D.E.; Jones, J. Isolation and identification of four flavonoid constituents from the seeds of Oroxylum indicum by high-speed counter-current chromatography. J. Chromatogr. A. 2003, 988, 95-105. [CrossRef]

8. Chen, L.J.; Song, H.; Lan, X.Q.; Games, D.E.; Sutherland, I.A. Comparison of high-speed counter-current chromatography instruments for the separation of the extracts of the seeds of Oroxylum indicum. J. Chromatogr. A 2005, 1063, 241-245. [CrossRef] [PubMed]

9. Zaveri, M.; Khandhar, A.; Jain, S. Quantification of baicalein, chrysin, biochanin-A and ellagic acid in root bark of Oroxylum indicum by RP-HPLC with UV detection. Eurasian J. Anal. Chem. 2008, 3, 245-257.

10. Tomimori, T.; Imoto, Y.; Ishida, M.; Kizu, H.; Namba, T. Studies on the Nepalese crude drug. VIII. On the flavonoid constituents of the seed of Oroxylum indicum. Shoyakugaku Zasshi. 1988, 42, 98-101.

11. Roy, M.K.; Nakahara, K.; Na, T.V.; Trakoontivakorn, G.; Takenaka, M.; Isobe, S.; Tsushida, T. Baicalein, a flavonoid extracted from a methanolic extract of Oroxylum indicum inhibits proliferation of a cancer cell line in vitro via induction of apoptosis. Pharmazie 2007, 62, 149-153.

12. Subramanian, S.S.; Nair, A.G.R. Flavanoids of the leaves of Oroxylum indicum and Pajanelia longifolia. Phytochemistry 1972, 11, 439-440. [CrossRef]

13. Dey, A.K.; Mukherjee, A.; Das, P.C.; Chatterjee, A. Occurrence of aloe-emodin in the leaves of Oroxylum indicum Vent. Indian J. Chem. 1978, 16B, 1042.

14. Yuan, Y.; Hou, W.; Tang, M.; Luo, H.; Chen, L.J.; Guan, Y.H.; Sutherland, I.A. Separation of flavonoids from the leaves of Oroxylum indicum by HSCCC. Chromatographia 2008, 68, 885-892. [CrossRef]

15. Sithisarn, P.; Nantateerapong, P.; Rojsanga, P.; Sithisarn, P. Screening for antibacterial and antioxidant activities and phytochemical analysis of Oroxylum indicum fruit extracts. Molecules 2016, 21, 446. [CrossRef] [PubMed]

16. Rojsanga, P.; Bunsupa, S.; Brantner, A.H.; Sithisarn, P. Comparative phytochemical profiling and in vitro antioxidant activity of extracts from raw materials, tissue-cultured plants, and callus of Oroxylum indicum (L.) Vent. Evid. Based Complement. Alternat. Med. 2017, 2017, 1-11. [CrossRef]

17. Association of Official Analytical Chemists (AOAC). Guidelines for Single Laboratory Validation of Chemical Methods for Dietary Supplements and Botanicals; AOAC International: Rockville, MD, USA, 2013.

18. Ahad, A.; Ganai, A.A.; Sareer, O.; Najm, M.Z.; Kausar, M.A.; Mohd, M.; Siddiqui, W.A. Therapeutic potential of Oroxylum indicum: A review. J. Pharm. Res. Opin. 2012, 2, 163-172.

19. Matsumoto, T.; Kaneko, A.; Koseki, J.; Matsubara, Y.; Aiba, S.; Yamasaki, K. Pharmacokinetic study of bioactive flavonoids in the traditional Japanese medicine Keigairengyoto exerting antibacterial effects against Staphylococcus aureus. Int. J. Mol. Sci. 2018, 19, 328. [CrossRef] [PubMed] 
20. Kumar, S.; Pandey, A.K. Chemistry and biological activities of flavonoids: An overview. Sci. World J. 2013, 2013, 1-16. [CrossRef] [PubMed]

21. Chen, Y.; Liu, T.; Wang, K.; Hou, C.; Cai, S.; Huang, Y.; Du, Z.; Huang, H.; Kong, J. Baicalein inhibits Staphylococcus aureus biofilm formation and the quorum sensing system in vitro. PLoS ONE 2016, 11, e0153468. [CrossRef] [PubMed]

22. Cushnie, T.P.T.; Lamb, A.J. Antimicrobial activity of flavonoids. Int. J. Antimicrob. Agents 2005, 26, 343-356. [CrossRef] [PubMed]

23. O’Leary, K.A.; Day, A.J.; Needs, P.W.; Sly, W.S.; O’Brien, N.M.; Williamson, G. Flavonoid glucuronides are substrates for human liver L-glucuronidase. FEBS Lett. 2001, 503, 103-106. [CrossRef]

24. Sousa, A.; Ferreira, I.; Calhelha, R.; Andrade, P.; Valentao, P.; Seabra, R.; Estevinho, L.; Bento, A.; Pereira, J.A. Phenolics and antimicrobial activity of traditional stoned table olives 'alcaparra'. Bioorg. Med. Chem. 2006, 14, 8533-8538. [CrossRef] [PubMed]

25. Luo, J.; Dong, B.; Wang, K.; Cai, S.; Liu, T.; Cheng, X.; Lei, D.; Chen, Y.; Li, Y.; Kong, J.; Chen, Y. Baicalin inhibits biofilm formation, attenuates the quorum sensing-controlled virulence and enhances Pseudomonas aeruginosa clearance in a mouse peritoneal implant infection model. PLoS ONE 2017, 28, e0176883. [CrossRef]

26. Zhang, Y.; Qi, Z.; Liu, Y.; He, W.; Yang, C.; Wang, Q.; Dong, J.; Deng, X. Baicalin protects mice from lethal infection by Enterohemorrhagic Escherichia coli. Front Microbiol. 2017, 9, 395. [CrossRef]

27. Baron, E.J.; Pererson, L.R.; Finegold, S.M. (Eds.) Bailey and Scott's Diagnostic Microbiology, 9th ed.; CVMosby: St. Louis, MO, USA, 1997.

Sample Availability: Samples of the compounds are not available from the authors.

(C) 2019 by the authors. Licensee MDPI, Basel, Switzerland. This article is an open access article distributed under the terms and conditions of the Creative Commons Attribution (CC BY) license (http://creativecommons.org/licenses/by/4.0/). 